\title{
PHYTOSTEROLS IN THE SEEDS OF WILD SUNFLOWER SPECIES
}

\author{
Fernández-Cuesta, Á., Velasco, L. and Fernández-Martínez, J.M. *
}

Instituto de Agricultura Sostenible (CSIC), Alameda del Obispo s/n, E-14004 Córdoba, Spain

Received: November 15, 2011 Accepted: December 10, 2011

\section{SUMMARY}

Ingestion of phytosterols prevents intestinal absorption of cholesterol in humans and results in a lowering of serum cholesterol, which has stimulated the use of phytosterols as enriched food ingredients in functional foods. Sunflower seeds and oils are rich sources of phytosterols. The variation reported for these compounds in cultivated sunflower germplasm is low. As for many other traits, wild sunflower species may contain valuable unexplored variation for phytosterol content and profile. The objective of this research was to evaluate the variation for seed phytosterols in a set of 47 wild Helianthus species from the USDA-ARS collection. An impressive variation was identified for total phytosterol content ( 1017 to $4308 \mathrm{mg} \mathrm{kg}^{-1}$ seed) and proportion of individual phytosterols, particularly campesterol (5.1 to $16.3 \%$ ), stigmasterol (3.1 to $23.9 \%$ ), beta-sitosterol ( 35.1 to $72.3 \%$ ), delta-5-avenasterol ( 1.9 to $20.5 \%)$, delta-7-stigmastenol ( 1.1 to $20.3 \%$ ), and delta-7-avenasterol (0.3 to $10.6 \%)$. Some of the extremes of these ranges of variation have not been identified in cultivated sunflower. The feasibility of transferring genes determining interesting phytosterol traits to cultivated sunflower should be investigated.

Key words: genetic diversity, germplasm evaluation, Helianthus spp., phytosterols, wild species, variability

\section{INTRODUCTION}

Phytosterols or plant sterols are natural constituents of plants that belong to the group of isoprenoids. They have a molecular nucleus of 17 carbons and a typical three-dimensional arrangement of four rings. Phytosterols play essential functions in plant cells such as regulation of fluidity and permeability of cell membranes, in a similar manner to cholesterol in mammalian cell membranes (Hartmann, 1998). They are very important for human nutrition. The ingestion of phytosterols prevents intestinal absorption of cholesterol in humans, resulting in a

* Corresponding author: Phone: +34-957-499204; Fax: +34-957-499252;

e-mail: jfernandezm@ias.csic.es 
lowering of serum cholesterol (Pollack, 1953; Andersson et al., 2004) and exhibit other beneficial properties such as anti-inflammatory and anti-tumor activities (Tapiero et al., 2003). These findings stimulated interest in the use of phytosterols and related compounds for enrichment of food products (Berger et al., 2004). The use of phytosterols as enriched food ingredients in functional foods has increased in recent years (Hearly et al., 2008). Phytosterols have also been used by the cosmetic industry as emulsifiers and in the pharmaceutical industry to obtain therapeutic steroid hormones (Clark, 1996). There are more than 250 different phytosterols in higher plants, with beta-sitosterol, campesterol and stigmasterol being generally predominant (Piironen et al., 2000). The oil of cultivated sunflower possesses a moderate average phytosterol content content of $3917 \mathrm{mg} \mathrm{kg}^{-1}$, predominantly made up of beta-sitosterol, compared with other oil seeds as corn ( $11700 \mathrm{mg} \mathrm{kg}^{-1}$ oil) and rapeseed (6119 $\mathrm{mg} \mathrm{kg}^{-1}$ oil) (Padley et al., 1994). No breeding research has been conducted to increase phytosterol content in sunflower seeds (Fernandez-Martinez et al., 2009). Both the increase of total phytosterol content in the seeds and the development of alternative phytosterol profiles could have potential economic importance and could be considered as additional objectives in breeding programs for seed oil quality in sunflower.

For other important seed quality traits such as fatty acids and tocopherols, breeding research in sunflower led to the development of germplasm with modified fatty acids (Soldatov, 1976; Osorio et al., 1995) and tocopherol profiles (Demurin et al., 1996; Velasco et al., 2004a) or increased total tocopherol accumulation in the seeds (Velasco et al., 2010). This progress was possible by the development of fast and reliable methods of analysis using extraction and preparation of samples for the GC or HPLC directly on the seeds (Garcés and Mancha, 1993; Goffman et al., 1999). These methods allowed the analysis of a large number of very small samples (individual or half seeds) and made the identification of variability for these traits possible. A similar method, allowing extraction and preparation of phytosterols for the GC directly on sunflower seeds, has been recently developed (FernándezCuesta et al., 2011).

Genetic sources of modified oil quality traits have been identified in germplasm of wild sunflower species. These included useful variants for fatty acid composition such as high linoleic acid (De Haro and Fernández-Martínez, 1991), low levels of total saturated fatty acids (Seiler, 1994, 1996) or tocopherol content and composition (Velasco et al., 2004b). The objective of this research was to evaluate the variation for total phytosterol content and composition of wild Helianthus species in germplasm.

\section{MATERIALS AND METHODS}

The plant material evaluated comprised 464 accessions representing 62 taxa of 47 Helianthus species, 21 of them from annual species and 41 of them from peren- 
nial species. The accessions were obtained from USDA-ARS Regional Plant Introduction Station (PI), Ames, IA. A set of 87 inbred lines from different origin (Fernandez-Cuesta et al., 20011) were used as cultivated checks.

Analyses of phytosterol content and profile were carried out following the method of Fernández-Cuesta et al. (2011). Twelve seeds per accession were weighted and placed in 10-ml propylene tubes. Two-hundred $\mu \mathrm{l}$ of internal standard solution prepared by dissolving cholesterol (99\% purity, reference C8667, SigmaAldrich, St. Louis, MO, USA) in hexane-ethanol (3:2) solution at a concentration of $0.1 \%$ were added. Alkaline hydrolysis was performed by adding $2 \mathrm{ml}$ of a solution of potassium hydroxide dissolved in ethanol at a concentration of $2 \%$. Seeds were crushed and homogenized in a homogenizer (Heidolph RC 500, Kelheim, Germany) equipped with a stainless-steel rod of $8 \mathrm{~mm}$ diameter at a speed of 5,000 rpm for about $15 \mathrm{sec}$. Seed rests in the rod were washed with $1 \mathrm{ml}$ of the ethanolic solution of potassium hydroxide and collected in the tube. The tubes were then left in a water bath at $80^{\circ} \mathrm{C}$ for $15 \mathrm{~min}$. Phytosterols were extracted by vortexing with $1 \mathrm{ml}$ hexane and $1.5 \mathrm{ml}$ water. The upper hexane layer was transferred to $2 \mathrm{ml}$ glass vials that were maintained in an oven at $37.5^{\circ} \mathrm{C}$ overnight. Fifty $\mu \mathrm{l}$ hexane and $50 \mu \mathrm{l}$ silylating mixture composed of pyridine:hexamethyldisilazane: trimethylchlorosilane 9:3:1 by vol (Silan-Sterol-1, reference 355650.0922, Panreac Química, Barcelona, Spain) were added to the dried pellets and the vials were left at the room temperature for $15 \mathrm{~min}$. The solution was transferred to $2 \mathrm{ml}$ vials containing 200 $\mu \mathrm{l}$ inserts and centrifuged at 4,000 rpm for $10 \mathrm{~min}$ (Unicen 21, Ortoalresa, Madrid, Spain). The vials were capped and conserved at $-20^{\circ} \mathrm{C}$. Gas chromatographic analysis was performed on a Perkin Elmer Clarus 600 GC equipped with a ZB-5 capillary column (id $=0.25 \mathrm{~mm}$, length $=30 \mathrm{~m}$, film thickness $=0.10 \mu \mathrm{m}$; Phenomenex, Torrance, CA, USA). Hydrogen was used as carrier gas at a pressure of $125 \mathrm{KPa}$. Split injector and flame ionization detector were maintained at $320^{\circ} \mathrm{C}$. The oven thermal regime was the following: initial temperature of $240^{\circ} \mathrm{C}$ was increased at $5^{\circ} \mathrm{C}$ $\mathrm{min}^{-1}$ to final temperature of $265^{\circ} \mathrm{C}$ and held for $10 \mathrm{~min}$. Total analytical time was 15 min. Total phytosterol content was calculated as the sum of individual phytosterols and expressed as $\mathrm{mg} \mathrm{kg}^{-1}$ seed.

Correlation coefficients were calculated using IBM SPSS Statistics 17.0 software.

\section{RESULTS AND DISCUSSION}

Phytosterol content averaged $2337.0 \mathrm{mg} \mathrm{kg}^{-1}$ seed in the analyzed accessions of wild Helianthus spp., compared with a phytosterol content of $2247.1 \mathrm{mg} \mathrm{kg}^{-1}$ seed of cultivated checks (Table 1). Wild accessions of $H$. annuus was on average 2060.8 $\mathrm{mg} \mathrm{kg}^{-1}$ seed, which was below the average levels of the rest of annual species, particularly $H$. praecox and $H$. porteri (Table 2 ) although the latter is not included in the series annui. The largest phytosterol content in all the accessions evaluated 
HELIA, 34, Nr. 55, p.p. 31-38, (2011)

Table 1: Mean, minimum and maximum values of total phytosterol content ( $\left.\mathrm{mg} \mathrm{kg}^{1} \mathrm{seed}\right)$ and profile (\% of total phytosterols) in seeds of 464 accessions of 47 Helianthus species and cultivated checks.

\begin{tabular}{lcccccc}
\hline \multirow{2}{*}{ Trait, 1 Helianthus species } & \multicolumn{3}{c}{ Cultivated checks $^{3}$} \\
\cline { 2 - 7 } & Mean & Min & Max & Mean & Min & Max \\
\hline Total $\left(\mathrm{mg} \mathrm{kg}^{-1}\right)$ & 2337.0 & 1017.4 & 4308.1 & 2247.1 & 1426.0 & 4710.0 \\
Camp (\%) & 9.8 & 5.1 & 16.3 & 8.0 & 3.8 & 16.7 \\
Stig (\%) & 13.2 & 3.1 & 23.9 & 8.1 & 5.2 & 14.2 \\
Sito (\%) & 56.2 & 35.0 & 72.3 & 56.7 & 45.1 & 65.0 \\
D5av (\%) & 8.9 & 1.9 & 20.5 & 1.5 & 0.4 & 9.7 \\
D7stig (\%) & 6.4 & 1.1 & 20.3 & 17.6 & 6.6 & 29.5 \\
D7av (\%) & 4.2 & 0.3 & 10.6 & 3.5 & 1.4 & 6.3 \\
\hline
\end{tabular}

${ }^{1}$ Camp =Campesterol; Stig=Stigmasterol; Sito=beta-sitosterol; D5av=delta-5-avenasterol;

D7stig=delta-7-stigmastenol; D7av=delta-7-avenasterol

${ }^{2}$ Other sterols detected in lower concentrations included delta-7-campesterol, clerosterol, and delta5,24-stigmastadienol

3Data from 87 cultivated inbred lines (Fernández-Cuesta et al., 2011)

Table 2: Number of accessions analyzed and average values for total phytosterol content (mg $\mathrm{kg}^{-1}$ seed) and phytosterol profile (\% of the total phytosterols) in 21 annual Helianthus species and subspecies

\begin{tabular}{|c|c|c|c|c|c|c|c|c|}
\hline Species & $\mathrm{N}$ & Total & Camp & Stig & Sito & D5av & D7stg & D7av \\
\hline H. annuus & 88 & 2060.9 & 11.4 & 11.6 & 54.9 & 6.3 & 9.3 & 5.3 \\
\hline H. anomalus & 4 & 2530.6 & 6.9 & 5.0 & 53.9 & 11.5 & 14.3 & 7.0 \\
\hline H. argophyllus & 12 & 2282.6 & 8.5 & 13.3 & 54.3 & 9.5 & 8.1 & 5.5 \\
\hline H. bolanderi & 5 & 2424.9 & 10.3 & 13.4 & 50. & 7.8 & 10.6 & 6.1 \\
\hline H. debilis cucumerifolius & 14 & 2395.2 & 9.2 & 14.8 & 50.5 & 11.2 & 7.5 & 6.3 \\
\hline H. debilis silvestris & 5 & 2175.3 & 9.6 & 14.3 & 51.5 & 12.2 & 6.6 & 5.8 \\
\hline H. debilis tardiflorus & 3 & 2237.2 & 10.2 & 16.2 & 50.4 & 10.8 & 6.9 & 5.4 \\
\hline H. debilis vestitus & 3 & 2283.0 & 8.9 & 18.5 & 46.2 & 10.9 & 8.3 & 7.1 \\
\hline H. deserticola & 6 & 2469.2 & 9.1 & 9.8 & 50.1 & 12.5 & 9.6 & 7.7 \\
\hline H. exilis & 7 & 2147.6 & 8.9 & 14.4 & 56.8 & 6.6 & 7.3 & 4.7 \\
\hline H. neglectus & 9 & 2021.9 & 8.5 & 12.2 & 52.6 & 5.5 & 12.0 & 7.7 \\
\hline H. niveus & 1 & 2526.0 & 7.5 & 7.5 & 54.9 & 11.8 & 10.8 & 6.1 \\
\hline H. niveus tephrodes & 4 & 2722.1 & 8.6 & 9.3 & 50.3 & 12.2 & 11.1 & 6.5 \\
\hline H. petiolaris & 6 & 2105.0 & 9.7 & 11.7 & 57.3 & 8.3 & 7.6 & 4.2 \\
\hline H. petiolaris fallax & 8 & 2541.2 & 9.2 & 10.7 & 54.5 & 10.5 & 8.9 & 5.0 \\
\hline H. petiolaris petiolaris & 20 & 2411.3 & 9.4 & 12.5 & 54.1 & 8.6 & 7.4 & 6.4 \\
\hline H. porteri & 4 & 3336.1 & 10.1 & 15.0 & 52.7 & 10.9 & 5.2 & 4.7 \\
\hline H. praecox & 2 & 2825.8 & 7.5 & 11.7 & 54.9 & 12.3 & 6.8 & 5.3 \\
\hline H. praecox hirtus & 4 & 3148.7 & 9.2 & 15.6 & 50.6 & 11.2 & 4.1 & 6.3 \\
\hline H. praecox praecox & 4 & 3188.9 & 8.0 & 11.6 & 49.5 & 10. & 13.0 & 5.4 \\
\hline H. praecox runyonii & 7 & 2888.8 & 8.5 & 12.2 & 52.4 & 10.44 & 9.3 & 5.3 \\
\hline Mean & & 2296.1 & 10.0 & 12.3 & 53.6 & 8.4 & 9.0 & 5.7 \\
\hline Cultivated checks ${ }^{3}$ & & 2247.1 & 8.0 & 8.1 & 56.7 & 1.5 & 17.6. & 3.5 . \\
\hline
\end{tabular}

${ }^{1}$ Camp=Campesterol; Stig=Stigmasterol; Sito=beta-sitosterol; D5av=delta-5-avenasterol; D7stig=delta-7-stigmastenol; D7av=delta-7-avenasterol

${ }^{2}$ Other sterols detected in lower concentrations included delta-7campesterol and delta-5,24-stigmastadienol

${ }^{3}$ Data from 87 cultivated inbred lines (Fernández-Cuesta et al., 2011) 
Table 3: Number of accessions analyzed and average values for total phytosterol content (mg $\mathrm{kg}^{-1}$ seed) and phytosterol profile (\% of the total phytosterols) in 41 perennial Helianthus species and subspecies

\begin{tabular}{|c|c|c|c|c|c|c|c|c|}
\hline Species & $\mathrm{N}$ & Total & Camp & Stig & Sito & D5av & D7stg & D7av \\
\hline H. arizonensis & 2 & 2545.2 & 10.9 & 11.9 & 53.2 & 13.5 & 5.2 & 4.7 \\
\hline H. atrorubens & 7 & 2902.2 & 8.9 & 14.7 & 57.6 & 9.9 & 4.6 & 3.7 \\
\hline H. californicus & 6 & 2571.7 & 7.9 & 13.9 & 52.6 & 9.8 & 9.9 & 5.0 \\
\hline H. carnosus & 2 & 2902.5 & 6.1 & 19.0 & 62.4 & 0.0 & 7.7 & 4.9 \\
\hline H. ciliaris & 7 & 2235.1 & 12.1 & 16.6 & 47.2 & 11.3 & 6.7 & 5.8 \\
\hline H. cusickii & 6 & 2535.4 & 9.7 & 13.0 & 56.7 & 8.9 & 6.2 & 4.6 \\
\hline H. decapetalus & 8 & 2073.8 & 9.4 & 13.9 & 61.2 & 9.0 & 3.5 & 2.4 \\
\hline H. divaricatus & 9 & 1967.0 & 9.7 & 13.3 & 60.7 & 9.0 & 3.4 & 2.6 \\
\hline H. eggertii & 5 & 1851.4 & 9.3 & 13.0 & 62.3 & 8.9 & 2.9 & 2.4 \\
\hline H. floridanus & 4 & 2577.3 & 8.9 & 22.1 & 50.3 & 7.1 & 6.1 & 3.9 \\
\hline H. giganteus & 9 & 2421.6 & 11.4 & 15.3 & 58.7 & 8.8 & 2.3 & 2.2 \\
\hline H. glaucophyllus & 4 & 2488.5 & 9.1 & 11.4 & 60.0 & 13.5 & 2.4 & 2.4 \\
\hline H. gracilentus & 4 & 2144.1 & 6.6 & 13.4 & 56.4 & 9.2 & 7.6 & 4.9 \\
\hline H. grosseserratus & 13 & 2582.8 & 9.5 & 14.4 & 59.2 & 9.1 & 2.9 & 3.0 \\
\hline H. heterophyllus & 2 & 3221.8 & 5.3 & 14.6 & 59.8 & 9.7 & 4.7 & 4.1 \\
\hline H. hirsutus & 6 & 1817.9 & 9.1 & 12.1 & 62.5 & 7.1 & 5.1 & 2.8 \\
\hline H. laevigatus & 4 & 2363.5 & 10.5 & 15.1 & 62.4 & 6.4 & 2.3 & 1.9 \\
\hline H. longifolius & 2 & 2625.6 & 9.0 & 17.6 & 54.7 & 9.1 & 3.9 & 1.4 \\
\hline H. maximilianii & 14 & 2722.0 & 8.8 & 12.6 & 55.8 & 8.4 & 8.2 & 4.7 \\
\hline H. microcephalus & 5 & 2492.9 & 11.6 & 11.1 & 60.6 & 9.8 & 3.2 & 2.4 \\
\hline H. mollis & 8 & 2143.2 & 8.8 & 15.9 & 60.4 & 4.9 & 5.7 & 2.8 \\
\hline H. nuttallii & 6 & 2621.9 & 9.4 & 15.2 & 60.6 & 7.5 & 3.4 & 2.3 \\
\hline H. nuttallii nuttallii & 7 & 3318.9 & 9.3 & 15.0 & 55.6 & 10.2 & 4.1 & 3.0 \\
\hline H. nuttallii rydbergii & 6 & 2616.5 & 10.7 & 16.4 & 59.2 & 5.8 & 3.4 & 2.3 \\
\hline H. occidentalis & 1 & 3401.6 & 10.4 & 16.8 & 54.2 & 12.0 & 4.0 & 1.7 \\
\hline H. occ. occidentalis & 1 & 2722.8 & 8.5 & 17.4 & 60.4 & 3.6 & 6.6 & 1.7 \\
\hline H. occ. plantagineum & 5 & 2850.5 & 7.7 & 17.2 & 58.7 & 9.7 & 4.1 & 1.6 \\
\hline H. pauciflorus & 6 & 2492.9 & 10.5 & 13.2 & 62.0 & 7.6 & 4.1 & 1.5 \\
\hline H. p. pauciflorus & 7 & 2355.6 & 11.2 & 11.3 & 59.7 & 11.4 & 3.5 & 1.7 \\
\hline H. p. subrhomboideus & 6 & 2349.1 & 9.8 & 14.5 & 60.6 & 10.3 & 2.6 & 1.0 \\
\hline H. pumilus & 10 & 2577.6 & 10.1 & 9.2 & 60.1 & 9.0 & 5.8 & 4.1 \\
\hline H. radula & 5 & 2898.8 & 8.9 & 19.8 & 45.9 & 18.3 & 3.0 & 2.5 \\
\hline H. resinosus & 7 & 1706.1 & 9.7 & 15.6 & 57.4 & 11.4 & 2.2 & 2.2 \\
\hline H. salicifolius & 5 & 2023.6 & 10.4 & 14.4 & 60.2 & 10.2 & 2.1 & 1.8 \\
\hline H. silphioides & 4 & 2526.1 & 7.5 & 11.8 & 64.7 & 8.07 & 4.8 & 2.2 \\
\hline H. simulans & 1 & 1792.6 & 9.9 & 17.1 & 52.5 & 11.2 & 3.2 & 3.6 \\
\hline H. smithii & 3 & 1955.4 & 10.4 & 15.6 & 63.1 & 6.0 & 1.9 & 2.4 \\
\hline H. strumosus & 10 & 2000.4 & 9.8 & 11.8 & 61.9 & 11.1 & 1.8 & 2.1 \\
\hline H. tuberosus & 17 & 1972.5 & 9.9 & 11.3 & 63.1 & 10.1 & 1.8 & 2.3 \\
\hline H. verticillatus & 2 & 2664.6 & 9.1 & 15.1 & 57.8 & 11.5 & 2.9 & 2.8 \\
\hline H. xlaetiflorus & 4 & 2053.2 & 9.8 & 11.7 & 63.1 & 11.4 & 1.4 & 1.4 \\
\hline Mean & & 2386.0 & 9.6 & 14.0 & 58.6 & 9.3 & 4.2 & 2.9 \\
\hline Cultivated Checks ${ }^{3}$ & & 2247.1 & 8.0 & 8.1 & 56.7 & 1.5 & 17.6. & 3.5 \\
\hline
\end{tabular}

${ }^{\top}$ Camp=Campesterol; Stig=Stigmasterol; Sito=beta-sitosterol; D5av=delta-5-avenasterol; D7stig=delta-7-stigmastenol; D7av=delta-7-avenasterol

${ }^{2}$ Other sterols detected in lower concentrations included delta-7campesterol and delta-5,24-stigmastadienol

${ }^{3}$ Data from 87 cultivated inbred lines (Fernández-Cuesta et al., 2011) 
( $4308 \mathrm{mg} \mathrm{kg}^{-1}$ seed) was found in H. praecox subsp. hirtus (accession PI 468848). Several perennial species e.g. $H$. nuttallii subsp. nuttallii and $H$. occidentalis showed also much higher average values of total phytosterol content than that of cultivated checks (Table 3). The accession PI 531047 of the former species showed a content of $4265 \mathrm{mg} \mathrm{kg}^{-1}$ similar to that observed in $H$. praecox subsp. hirtus.

The average phytosterol profile of the evaluated germplasm consisted of $9.8 \%$ campesterol; $13.2 \%$ stigmasterol; $56.2 \%$ beta-sitosterol; $8.9 \%$ delta-5-avenasterol, $6.4 \%$ delta-7-stigmastenol and $4.2 \%$ delta-7-avenasterol. The proportions of stigmasterol and delta-5-avenasterol were higher in the wild species than in cultivated checks, whereas the proportion of delta-7-stigmastenol was higher in the cultivated checks (Tables, 1, 2 and 3). Moreover, the average values of delta-7-stigmastenol and delta-7-avenasterol were higher in the annual than in the perennial species (Tables 2 and 3). Considering all the accessions, wild Helianthus species included an impressive variability for individual phytosterols, such as campesterol (5.1 to $16.3 \%$ ), stigmasterol (3.1 to $23.9 \%$ ), beta-sitosterol (35.1 to $72.3 \%$ ) delta-5-avenasterol ( 1.9 to $20.5 \%$ ), delta-7-stigmastenol ( 1.1 to $20.3 \%$ ), and delta-7-avenasterol (0.3 to $10.6 \%$ ) (Table 1$)$. Some of the upper values of these ranges, namely the increased levels of stigmasterol identified in accession AMES 28377 of $\mathrm{H}$. floridanus, the increased levels of beta-sitosterol identified in accession PI 650028 of $\mathrm{H}$. pauciflorus subsp. pauciflorus and the increased levels of delta-5-avenasterol identified in the accession PI 597908 of $H$. debilis subsp. Cucumerifolius, were particularly remarkable. Further selection is needed to confirm and isolate variants from individual accessions with deviating values.

Total phytosterol content had a negative correlation with the percentage of campesterol and beta-sitosterol and a positive correlation with delta-5-avenasterol. Correlation coefficients between individual phytosterols are shown in Table 4. Negative correlations were observed between individual phytosterols except between delta-7-stigmastenol and delta-5-avenasterol that was positive and high. The strongest negative correlations involved beta-sitosterol with delta-5-avenasterol, delta-7stigmastenol and delta-5-avenasterol.

Table 4: Correlation coefficients among total seed phytosterol (Tot phy) content ( $\mathrm{mg} \mathrm{kg}^{-1}$ seed), and proportion of campesterol (Camp), stigmasterol (Stig), beta-sitosterol (Sito), Delta-5-avenasterol (D5av), Delta-7-stigmastenol (D7stig) and Delta-7-avenasterol (D7av), expressed in \% of total phytosterols.

\begin{tabular}{lcccccc}
\hline & Camp & Stig & Sito & D5av & D7stig & D7av \\
Tot phy & $-0.17^{\star \star}$ & $0.10^{\star}$ & $-0.22^{\star \star}$ & $0.27^{\star \star}$ & $-0.01 \mathrm{~ns}$ & $0.06 \mathrm{~ns}$ \\
Camp & & $-0.02 \mathrm{~ns}$ & $-0.09^{\star}$ & $-0.16^{\star \star}$ & $-0.16^{\star \star}$ & $-0.14^{\star \star}$ \\
Stig & & & $-0.22^{\star \star}$ & $-0.08 \mathrm{~ns}$ & $-0.29^{\star \star}$ & $-0.20^{\star \star}$ \\
beta-sit & & & & $-0.36^{\star \star}$ & $-0.53^{\star \star}$ & $-0.66^{\star \star}$ \\
D5av & & & & & $-0.27^{\star \star}$ & $0.01 \mathrm{~ns}$ \\
D7stig & & & & & & $0.68^{\star \star}$ \\
\hline
\end{tabular}

*,** significant at the $1 \%$ and $5 \%$ respectively; ns: not significant 
Previous studies have reported that wild Helianthus species contain useful variation for oil quality traits such as fatty acid composition of the oil, including variants for increased oleic acid content (Seiler, 1985), high linoleic acid content (De Haro and Fernández-Martínez, 1991), and low levels of total saturated fatty acids (Seiler, 1994, 1996), and also for tocopherol content and composition (Velasco et al., 2004b). Although further research at an intrapopulation level is needed to confirm and isolate variants, the results of the present research showed that wild Helianthus germplasm contains large variation for phytosterol content and profile that could be useful for breeding programs including these traits. Some of the ranges observed with extreme values in total content and in percentage of individual phytosterols have not been reported in cultivated sunflower. Moreover, some of the interesting traits were identified in annual species that are cross-bred easily with cultivated sunflower, thus facilitating their introgression.

The combination of variants for phytosterol content and profile with other quality traits such as specific fatty acid profiles and higher tocopherol content and/or specific tocopherol profiles could produce new oil types with unique nutritional and/or technological properties.

\title{
ACKNOWLEDGMENTS
}

\author{
The authors thank USDA-ARS Regional Plant Introduction Station, \\ Ames, IA, for sending Helianthus spp. accessions. The work was sup- \\ ported by research project P07-AGR-03011 from Junta de Andalucía \\ and EU FEDER funds.
}

\section{REFERENCES}

Andersson, S.W., Skinner, J., Ellegård, L., Welch, A.A., Bingham, S., Mulligan, A., Andersson, H. and Khaw, K.T., 2004. Intake of dietary plant sterols is inversely related to serum cholesterol concentration in men and women in the EPIC Norfolk population: a crosssectional study. Eur. J. Clin. Nutr. 58: 1378-1385.

Berger, A., Jones, P.J.H., and Abumwei, S.S., 2004. Plant sterols: factors affecting their efficacy and safety as functional food ingredients. Lipids Health Dis. 3: 5.

Clark, J., 1996. Tocopherols and sterols from soybeans. Lipid Technol. 8: 111-114.

De Haro, A. and Fernández-Martínez, J.M., 1991. Evaluation of wild sunflower (Helianthus) species for high content and stability of linoleic acid in the seed oil. J. Agric. Sci. 116: 359-367.

Demurin, Y., Škorić, D. and Karlović, D., 1996. Genetic variability of tocopherol composition in sunflower seeds as a basis of breeding for improved oil quality. Plant Breed. 115: 33-36.

Fernández-Cuesta, A., Aguirre-González, M.R., Ruiz-Méndez, M.V. and Velasco, L., 2011. Validation of a method for the analysis of phytosterols in sunflower seeds. Eur. J. Lipid Sci. Technol. (in press).

Fernández-Martínez, J.M., Perez-Vich, B. and Velasco, L., 2009. Sunflower. In: Vollmann, J. and Rajčan, I. (Eds.) Oil Crop Breeding, Springer, New York, pp. 155-232.

Garcés, R. and Mancha, M., 1993. One-step lipid extraction and fatty acid methyl esters preparation from fresh plant tissues. Anal. Biochem. 211: 139-143. 
Goffman, F.D., Velasco, L. and Thies, W., 1999. Quantitative determination of tocopherols in single seeds of rapeseed (Brassica napus L.). Fett/Lipid 101: 142-145.

Hartmann, M.A., 1998. Plant sterols and the membrane environment. Trends Plant Sci. 3: 170175.

Hearly, A., Duffy, E., Joyce, J., O’Connor, C. and Gibne, M.J., 2008. Phytosterol-enriched products on the Irish market: examination of intake and consumption patterns. Public Health Nutr. 12: 51-58.

Osorio, J., Fernández-Martínez, J.M., Mancha, M. and Garcés, R., 1995. Mutant sunflower with high concentration of saturated fatty acids in the oil. Crop Sci. 35: 739-742.

Padley, F.B., Gunstone, F.D. and Harwood, J.L., 1994. Occurrence and characteristics of oils and fats. In: F.D. Gunstone, J.L. Harwood, F.B. Padley (Eds.), The Lipid Handbook London: Chapman \& Hall, pp. 47-223.

Piironen, V., Lindsay, D.G., Miettinen, T.A., Toivo, J. and Lampi, A.M., 2000. Plant sterols: Biosynthesis, biological function and their importance to human nutrition. J. Sci. Food Agric. 80: 939-966.

Pollack, O.J., 1953. Reduction of blood cholesterol in man. Circulation 7: 702-706.

Seiler, G.J., 1985. Evaluation of seeds of sunflower species for several chemical and morphological characteristics. Crop Sci. 25: 183-187.

Seiler, G.J., 1994. Oil concentration and fatty acid composition of achenes of North American Helianthus (Asteraceae) species. Econ. Bot. 48: 271-279.

Seiler, G.J., 1996. Search for low saturated fatty acids in wild sunflowers. In: Proc. $18^{\text {th }}$ Sunflower Research Workshop, Fargo, ND, January 11-12, 1996, pp. 1-3.

Soldatov, K.I., 1976. Chemical mutagenesis in sunflower breeding. In: Proc. $7^{\text {th }}$ Int. Sunflower Conf., Krasnodar, USSR., pp. 352-357.

Tapiero, H., Towsend, D.M. and Tew, K.D., 2003. Phytosterols in the prevention of human pathologies. Biomed. Pharmacol. 57: 321-325.

Velasco, L., Pérez-Vich, B. and Fernández-Martínez, J.M., 2004a. Novel variation for tocopherol profile in a sunflower created by mutagenesis and recombination. Plant Breed. 123: 490492.

Velasco, L., Pérez-Vich, B. and Fernández-Martínez, J.M., 2004b. Evaluation of wild sunflower species for tocopherol content and composition. Helia 44: 361-362.

Velasco, L., Del Moral, L., Pérez-Vich, B. and Fernández-Martínez, J.M., 2010. Selection for contrasting seed tocopherol content in sunflower seeds. J. Agric. Sci. 148: 393-400.

\section{FITOESTEROLES EN LAS SEMILLAS DE ESPECIES SILVESTRES DE GIRASOL}

RESUMEN

La ingesta de fitoesteroles reduce la absorción intestinal de colesterol en humanos y da lugar a una disminución del colesterol sérico, lo que ha promovido el uso de los fitoesteroles como ingredientes de alimentos funcionales. Las semillas y aceite de girasol son fuentes ricas en fitoesteroles. La variación publicada para estos compuestos en el germoplasma de girasol cultivado es baja. Como para muchos otros caracteres, las especies silvestres de girasol pueden contener una variación valiosa sin explorar para contenido y perfil de fitoesteroles. El objetivo de este trabajo fue evaluar la variación para fitoesteroles en las semillas en un conjunto de 47 especies silvestres de Helianthus de la colección del USDA-ARS. Se identificó una enorme variación tanto para el contenido total de fitoesteroles (1017 a $4308 \mathrm{mg} \mathrm{kg}^{-1}$ de semilla) como para la proporción de fitoesteroles individuales, en particular de campesterol (5.1 a 16.3\%) estigmasterol (3.1 a 23.9\%), beta-sitosterol (35.1 a $72.3 \%$ ), delta-5-avenasterol ( 1.9 a $20.5 \%$ ), delta-7-estigmastenol ( 1.1 a $20.3 \%$ ) y delta-7-avenasterol (0.3 a $10.6 \%)$. Algunos de los extremos de estos rangos de variación no han sido identificados en el girasol cultivado. La posibilidad de transferencia de genes que determinan caracteres interesantes para fitoesteroles al girasol cultivado debe ser investigada. 